\title{
Hawaii
}

\section{- ferieparadis for vulkanelskere}

Kalakau Lookout på øen Kauai hvor man får et glimt af den spektakulcere Na Pali-kyst, der kun er tilgcengelig via havet eller vandrestier fra den nordlige del af øen. (Foto: Forfatteren)

Af geolog Susanne Plesner, laboratorieansvarlig, Vesla A/S

Turen gik i den forgangne sommer til omkring fire af de Hawaiianske øer, nærmere betegnet øerne Oahu, Maui, Big Island og Kauai. Besøgene på Maui og Big Island var et led $i$ en geologisk ekskursion for medlemmer af Geografforbundet, hvor det faglige indhold var tilrettelagt af forfatteren.

Hawaiiøerne, beliggende omtrent midt i Stillehavet, er dannet ved vulkansk aktivitet over et hotspot. De er en del af en lang række af seamounts, der kaldes for "Hawaiian Islands - Emperor Seamount"-kæden (se figuren til højre). Den strækker sig over ca. $6.000 \mathrm{~km}$ og har over 100 aktive og udslukte vulkaner. Mange af disse vulkaner har sandsynligvis på et tidspunkt være oversøiske, men i dag ligger langt det meste af "bjergkæden" under havets overflade. Kun øerne Niihau, Kauai, Oahu, Molokai, Lanai,
De udslukte, undersøiske vulkaner $i$ Hawaiian Islands - Emperor Seamount-bjergkceden afsluttes mod sydøst af Hawaiiøerne og den endnu undersøiske nye hawaiianske vulkan Loihi. Man ser endvidere $p a ̊$ kortet, at den pacifiske lithosforeplade har skiftet bevagelsesmønster på et tidspunkt. (Grafik: Forfatteren)

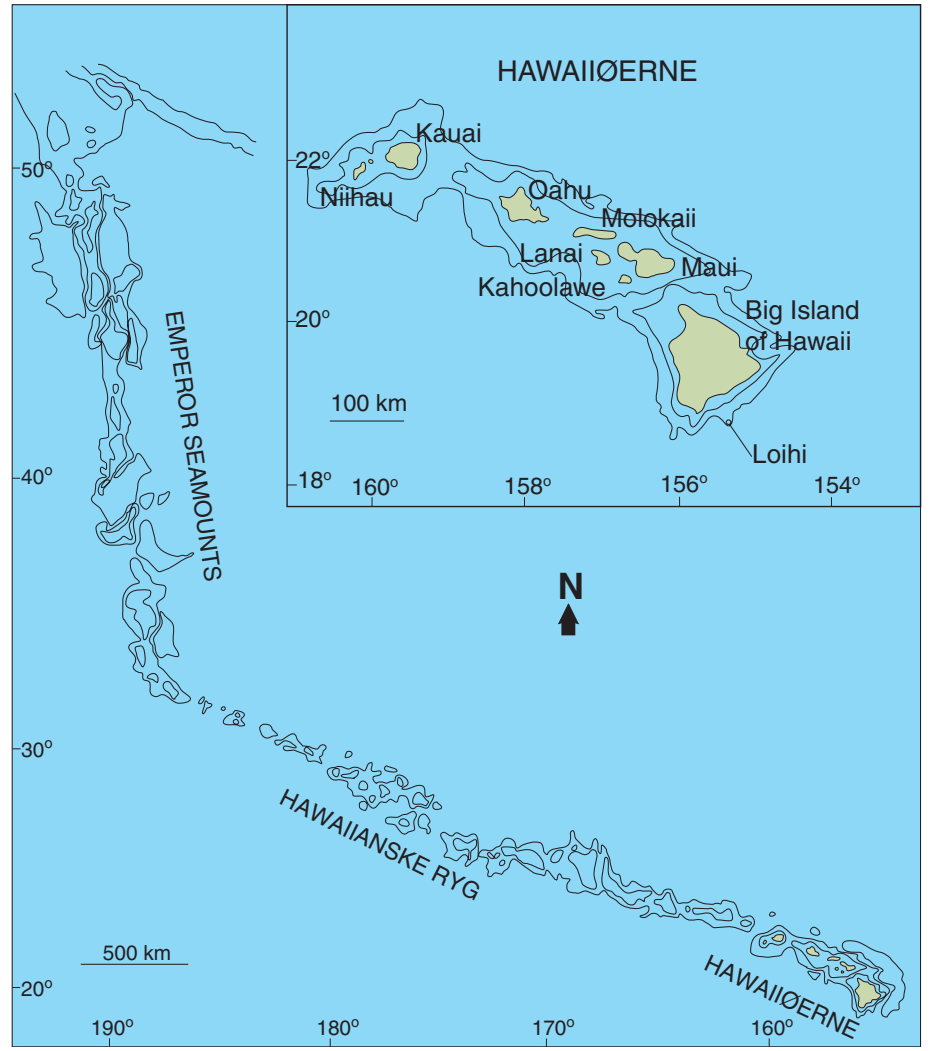


Maui, Kahoolawe og Hawaii længst mod sydøst i kæden er i dag landfaste.

\section{De ældste vulkaner}

De ældste vulkaner findes længst mod nordvest i kæden og er 75 til 80 millioner år gamle (og udslukte), mens de yngste stadig er aktive og ligger på den største af Hawaiiøerne og på seamount'et Loihi sydøst for førnævnte. Nogle forskere spår, at Loihi vil bryde op over havoverfladen om ca. 10.000 år. Af de i dag landfaste øer findes de ældste bjergarter på Niihau og Kauai og er ca. 6 millioner år gamle mens de yngste, som nævnt ovenfor, findes på Hawaiiøen, i daglig tale kaldet Big Island, som stadig oplever vulkansk aktivitet fra vulkanen Kilauea.

\section{Generelt om hawaiianske vulkaner}

Vulkanerne, der opbygger Hawaiiøerne, er skjoldvulkaner. De har som hovedregel udbrud fra centrale åbninger eller flankeudbrud eller begge dele. Det er skjold- eller kuppelformede vulkaner, der dannes af tyndtflydende lava, der langsomt løber ud og størkner over et stort areal. Det er derfor denne type vulkaner har svagt stigende skråninger ofte med hældninger på mindre end $10^{\circ}$. De er typisk asymmetriske, og det skyldes de hyppige udbrud fra vulkanernes riftzoner.

Hawaiianske vulkaner er typisk polygenetiske. Det vil sige, at de er opbygget af lava fra mange forskellige udbrud modsat monogenetiske vulkaner, der er dannet ved

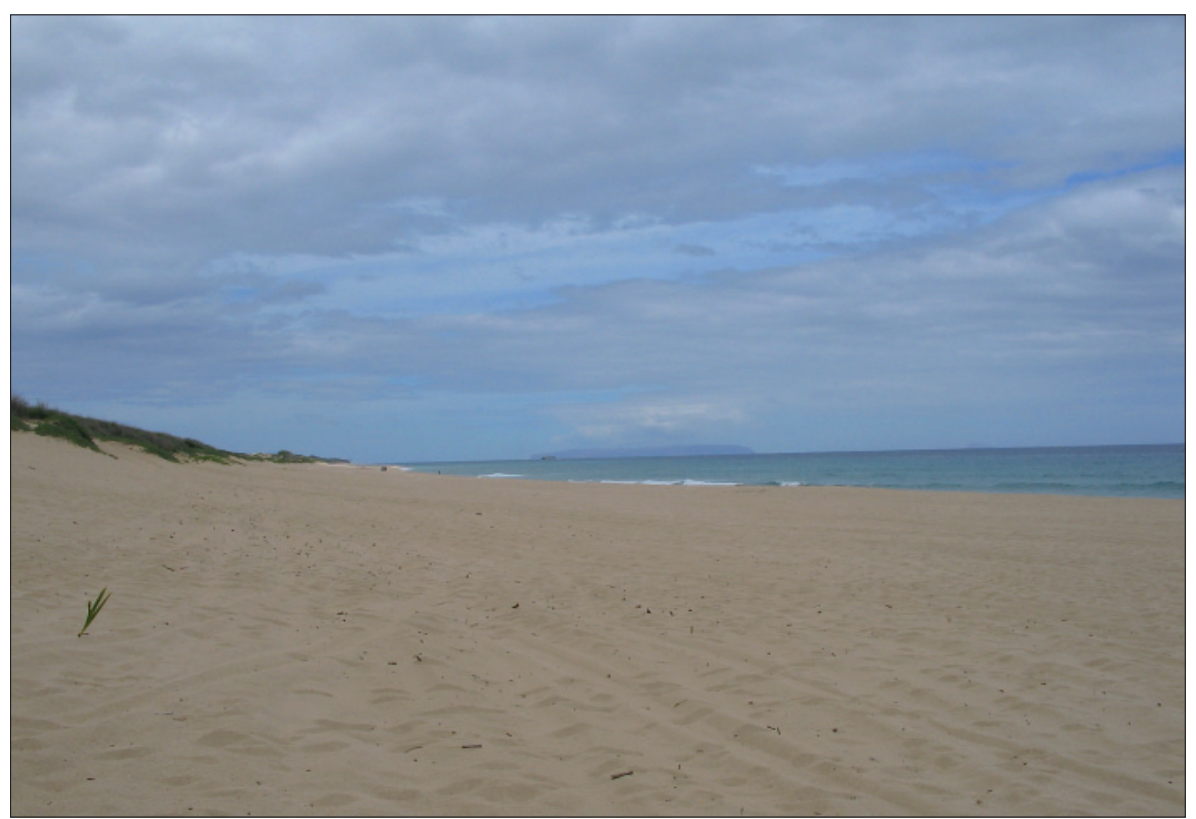

Sandet på den brede, hvide Polihale-strand på Kauai's vestkyst er en blanding af vulkansk materiale og ødelagte koraller i små bitte stykker, der er skyllet op på stranden over mange år. (Foto: Forfatteren)

lava fra et enkelt udbrud. Polygenetiske vulkaner udviser også meget større variation i sammensætningen af lavaerne. Begyndelsesfasen af et udbrud er typisk mere voldsom end senere i udbrudsfasen. Udbruddene begynder som oftest med, at lavaen bliver kastet op i fontæner (optil flere hundrede meter op i luften), mens rolige lavastrømme i lavatunneler og på overfladen præger de senere forløb. Det er det senere forløb af det

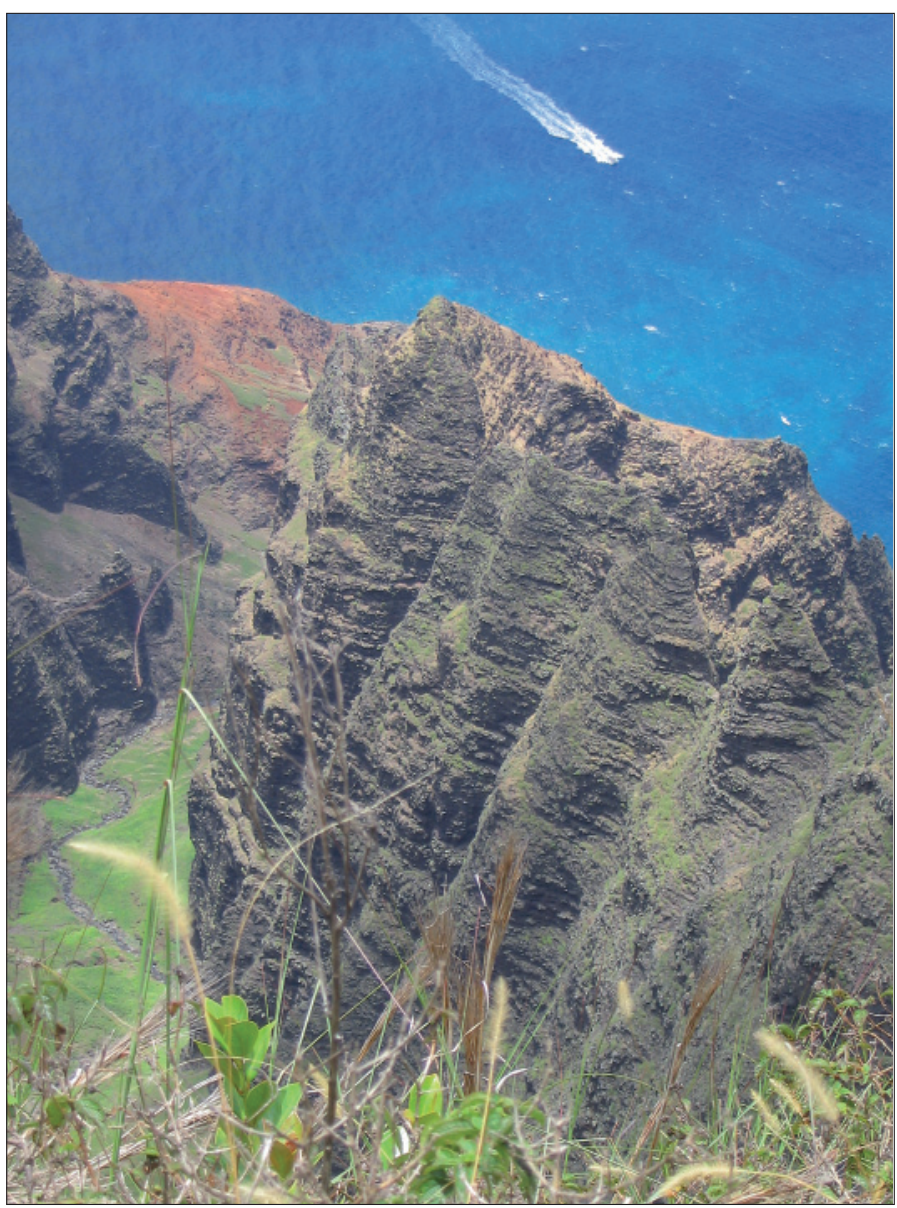

De høje klipper på Na Pali-kysten mod nordvest er et skoleeksempel på, hvad erosion ved hjcelp af rindende vand, vind og vejr kan gøre ved klipper af forskellig sammenscetningsmoessig beskaffenhed. Hvor der nogle steder dannes dybe dale og skår, ser man andre steder spir stå tilbage som stolte støtter. (Foto: Forfatteren igangværende udbrud fra Kilauea, vi ser på Big Island i dag.

Forskningen har vist, at hawaiianske vulkaner generelt gennemlever fire dannelsesfaser i deres levetid. Nævnt i rækkefølge begyndende med den ældste kaldes dannelsesfaserne for "før-skjoldbygningsfasen", "skjoldbygningsfasen", "efter-skjoldbygningsfasen" og "efter-erosionsfasen" eller "foryngelsesfasen". Den sidste fase kan indtræde så lang tid som flere millioner år efter den forudgående fase. Bjergarter fra den ældste dannelsesfase er ikke blottet nogle steder på øerne, så den viden, man har om denne fase, stammer fra undersøiske prøver fra Loihi Seamount. Ikke alle vulkaner gennemlever alle fire dannelsesfaser, men som hovedregel gør de dog. Faserne varierer både kemisk og volumenmæssigt, hvor den skjoldbyggende fase står for langt hovedparten af volumen, nemlig omkring $95 \%$ af den enkelte vulkan.

Variationerne i den kemiske sammensætning (og dermed også indirekte de volumenmæssige forskelle) af bjergarterne er en konsekvens af lithosfærepladens vandring hen over hotspottet.

Herunder er valgt nogle få ting ud til beskrivelse fra hver af de besøgte øer.

\section{Kauai}

Kauai og Niihau udgør med deres placering længst mod nordvest den ældste del af øgruppen. De ældste bjergarter her er omkring 6 millioner år gamle. Den seneste vulkanske aktivitet på Kauai repræsenterer den sidste dannelsesfase, "efter-erosionsfasen", og fandt sted for omkring 500.000 år siden. Det største volumen af bjergarter blev dog dannet for mellem 5 og 2,5 millioner år siden. Øen er næsten cirkulær, og man har i mange år troet, at den kun bestod af én skjoldvulkan, men de senere års forskning 
har vist, at det er mere kompliceret end som så. Den geologiske historie er dog ikke udredt endnu.

Øen fremstår i dag noget eroderet og meget frodig og grøn. Eftersom de seneste vulkanudbrud kun efterlod sig materiale på den østlige del af øen, har erosionen haft frit spil i længst tid på de centrale og vestlige dele af øen. Det har på vest- og nordvestkysten resulteret $\mathrm{i}$ henholdsvis brede, hvide sandstrande (billedet foregående side øverst) og dybe dale og skår i de høje klipper. Især nordvestkysten, Na Pali Coast, er særlig spektakulær med sine dybe skår, dale og høje spir, der i de fleste tilfælde er begroede og på lang afstand ser "bløde" og uldne ud (se billedet på foregående side nederst).

På det centrale Kauai ligger bjerget Mt. Waialeale, der får 12 meter regn om året, og dermed er det vådeste, landfaste sted på jorden. Den er indhyllet i skyer 350 dage om året og nærmest gold uden vegetation. Floder har gennem tusinder af år eroderet sig vej gennem terrænet fra Mt. Waialeale. Blandt andet gennem Waimea Canyon der oprindeligt blev skabt ved et stort jordskælv, der nær havde delt Kauai i to. Slugten er siden da blevet uddybet og udvidet ved erosion.

Fra Mt. Waialeale er floder gennem tusinder af år løbet gennem blandt andet Waimea Canyon og har eroderet sig gennem klipperne og dermed efterladt sig denne spektakulære slugt, der i dag er $16 \mathrm{~km}$ lang, godt halvanden kilometer bred og knap én kilometer dyb.

\section{Oahu}

Oahu har gennemlevet alle de fire dannelsesfaser. Den er nærmeste naboø i sydøstlig retning til Kauai og dermed også den næstældste af Hawaiiøerne. Øen er bygget op af lavastrømme fra to vulkaner, Waianae og Ko'olau der udgør henholdsvis den sydvestlige og den nordøstlige del af Oahu, og i dag fremstår den som to bjergkæder. Lavlandet imellem bjergkæderne består af lavastrømme fra dem begge.

I og omkring Hawaiis hovedstad, Honolulu, findes et kompleks af vulkankegler, vents (åbning i jordens overflade hvorfra vulkansk materiale kommer ud. Termen bruges også om tidligere åbninger, der nu er lukkede, men hvorfra der har været udbrud.) og associerede lavastrømme, der er et resultat af vulkansk aktivitet fra den sidste dannelsesfase, "efter-erosionsfasen". De er samtidig en del af Ko'olau-bjergkæden, som er omkring 2,6 millioner år gammel. En af tuff-keglerne er byens vartegn, Diamond Head. Sømænd tildelte keglen navnet Diamond Head fordi de fejlagtigt troede, at calcitkrystaller, der glimtede i solen, var diamanter. Diamond Head blev dannet ved et eksplosivt udbrud for ca. 200.000 år siden. Udbruddet varede kun få dage. Dengang var havniveauet højere end i dag, og det opstigende magmas kontakt med vandet

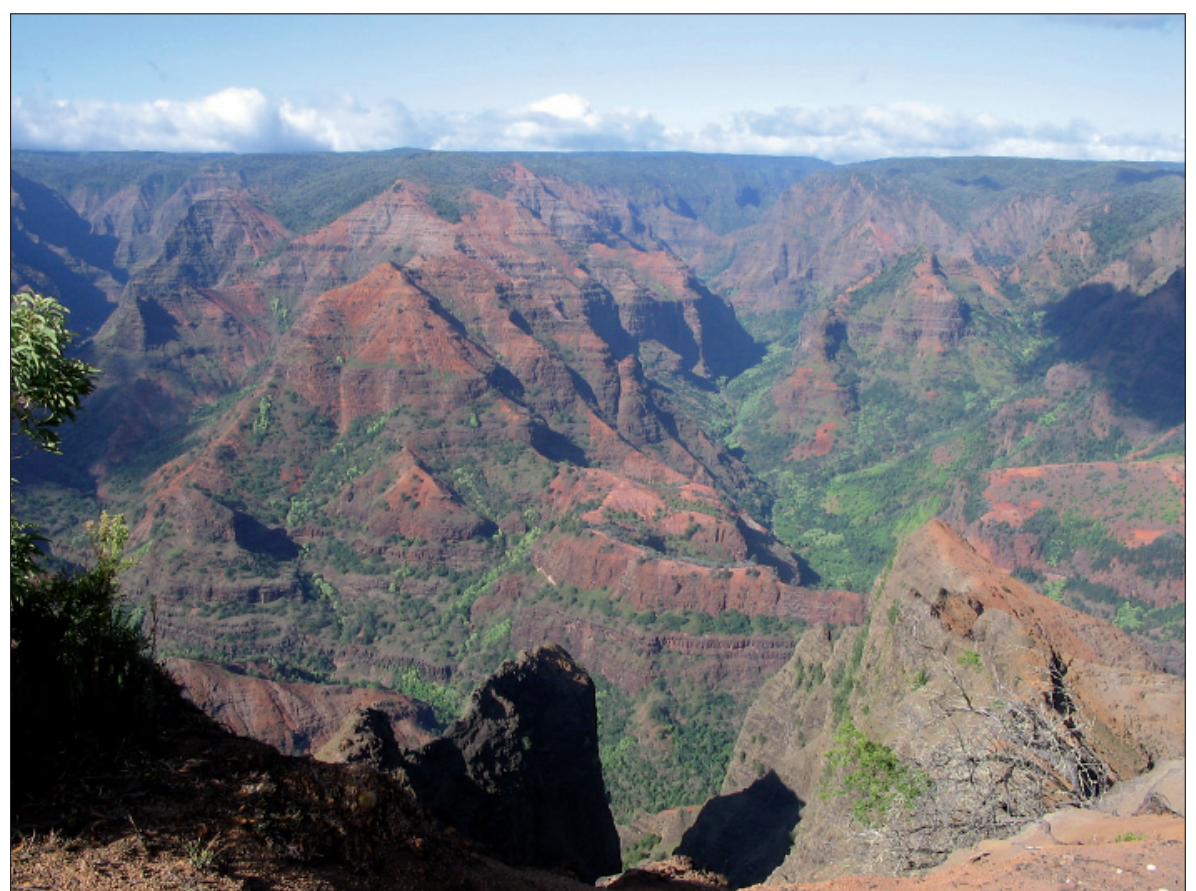

Rindende vand har gennem årtusinder gjort Waimea Canyon dybere og bredere. Den bliver også kaldt "Grand Canyon of the Pacific" og på trods af dens beskedne størrelse sammenlignet med Grand Canyon i det nordlige Arizona, er dette tilnavn dog let at forstå, når man står på et af de mange udsigtspunkter. (Foto: Forfatteren) har været medvirkende faktor til, at udbruddet blev eksplosivt.

\section{Maui}

Øen Maui ligger omtrent midt i øgruppen og består af to vulkaner, Vestmaui-vulkanen og Østmaui-vulkanen, som er "vokset sammen". Der er på begge vulkaner fundet udbrudsprodukter, som formodentlig er fra "efter-erosionsfasen", og de har derfor begge gennemlevet alle fire dannelsesfaser.

\section{Vestmaui}

Noget af det mest spektakulære ved Vestmauivulkanen er Iao Valley med Iao Needle (foto øverst på næste side). Iao Valley er mere eller mindre sammenfaldende med den gamle centrale caldera i vulkanen og har meget stejle sider. "Nålen" er i virkeligheden en smal ryg af basaltlavastrømme, der har modstået erosionen, sandsynligvis fordi de er gennemkrydset af mange vulkanske gange og derfor er mere resistente over for erosion.

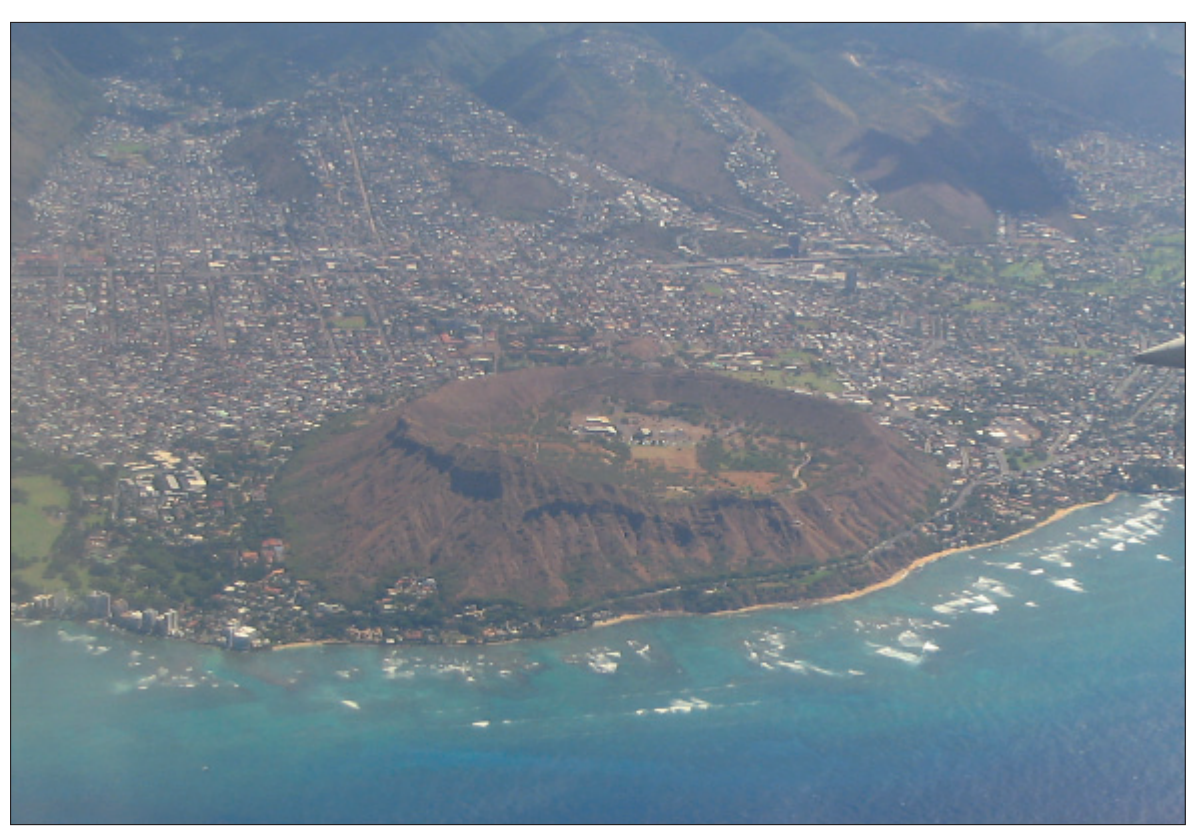

Diamond Head er ncermest cirkelrund, $1.066 \mathrm{~m}$ i diameter og $232 \mathrm{~m}$ dyb. Grunden til, at keglen er så symmetrisk, er, at udbruddet sandsynligvis var kort (2 - 3 dages varighed), og det nedfaldne tuff, som vulkankeglen består af, ikke er blevet transporteret ret langt med vinden. (Foto: Forfatteren) 


\section{Østmaui}

Østmaui vulkanen er mest kendt under navnet på topkrateret "Haleakala", der betyder "Solens hus". Haleakala er blevet kaldt det største udslukte vulkankrater i verden. Denne betegnelse er lidt misvisende pga. tre fohold: Haleakala-krateret er meget mindre end mange andre vulkankratere; der er en stor chance for at den ikke er udslukt (blot hvilende), og skal man være helt korrekt, er krateret ikke af vulkansk oprindelse, men derimod dannet ved erosion, selvom det befinder sig i en vulkan!

Krateret er $12 \mathrm{~km}$ langt og $4 \mathrm{~km}$ bredt og et pragtfuldt skue, når man står på kanten i godt 3.000 moh. (Se billede.) Det, der springer først i øjnene, er cinderkeglerne på bunden af krateret. De er dannet for nogle få tusind år siden under den seneste vulkansk aktive periode og er det overjordiske bevis for reaktiveringen af én af de tidligere aktive riftzoner. Det er ikke ualmindeligt, at den sidste af de fire dannelsesfaser "genbruger" riftzoner fra den tidligere dannelsesfase, og det er altså sket her.

Det samme fænomen ses ligeledes i form at cinderkegler på linje på Østmaui-vulkanens sydlige yderflanke (illustreret på fotoet øverst næste side). Den yngste vulkanske aktivitet på Østmaui fandt sted mellem 1.470 og 1.790 e. kr. og resulterede i lavastrømme uden for Haleakala-krateret. Man mener, at de seneste udbrudsperioder kan have varet så længe som 1.000 år adskilt af perioder med inaktivitet på 500-800 år.

\section{Klimatiske forskelle}

Ud over at være interessant set ud fra et vulkansk synspunkt danner Østmaui-vulkanen også et klimatisk skel. Mens nordkysten af østøen er frodig med regnskov - det rene mekka for botanikere (foto nederst på næste side) - fremstår sydsiden af øen meget tør og gold (fotoet øverst på næste side), der hvor der ikke kunstvandes. Det skyldes, at

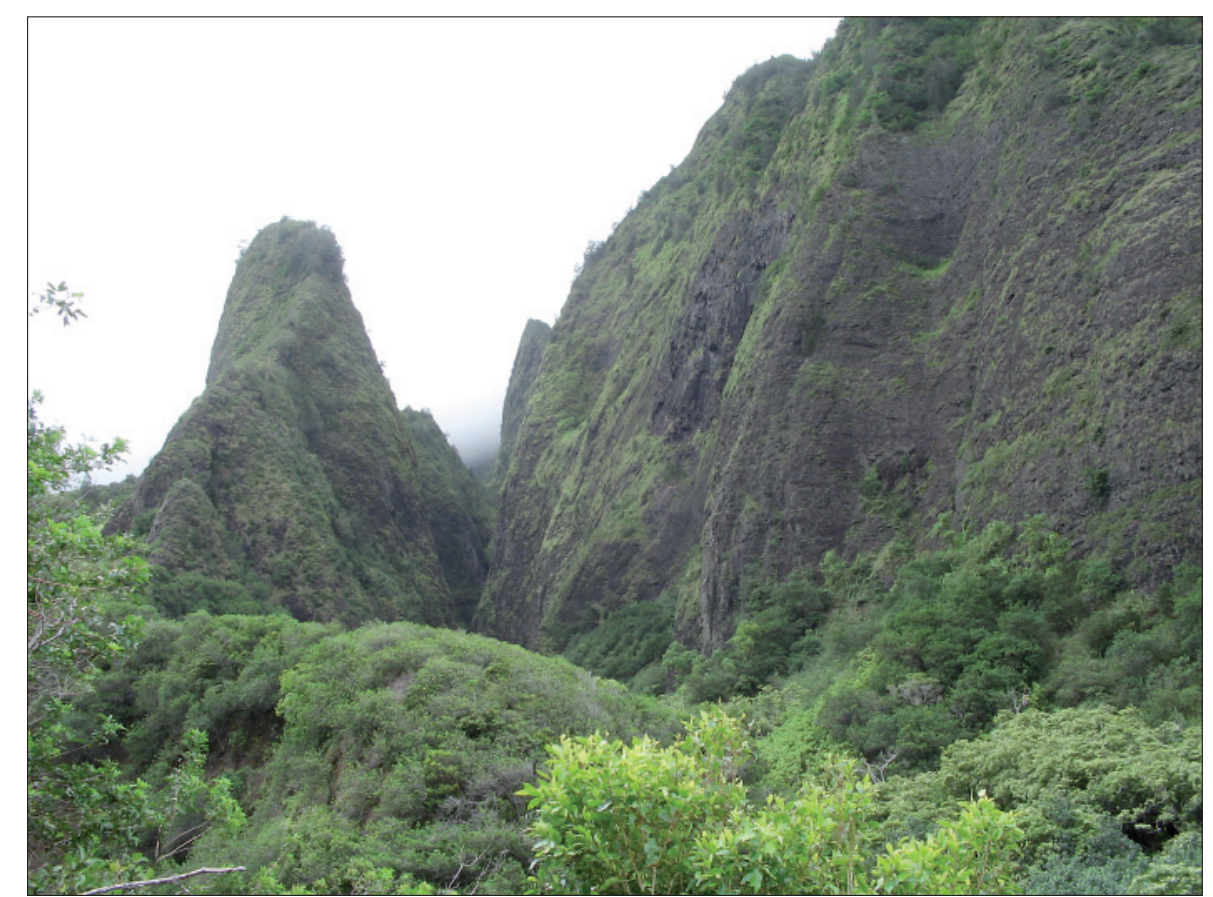

Iao Needle rager 365 op. Iao er hawaiiansk og betyder "højeste punkt" eller "rager ind $i$ himlen". Ud over at vare et naturskønt område med mange besøgende turister forbindes stedet også med flere store historiske begivenheder og sagn. (Foto: Forfatteren)

den fremherskende vind kommer fra nord, og på grund af de stejle sider på den godt 3.000 meter høje vulkan smider den al sin fugt her. Sydsiden får på denne måde næsten ingen regn, men derimod kun den tørre føhnvind. Der er således stor forskel på nord- og sydkysten, selvom der intet sted er mere end $50 \mathrm{~km}$ i luftlinje fra kyst til kyst.

\section{Big Island}

Big Island er opbygget af fem vulkaner: Kohala, Mauna Kea, Haulalai, Mauna Loa og Kilauea. Ligesom de vulkanske bjergarter i Hawaii-øgruppen generelt afspejler bevægelsen af den pacifiske plade, således at øerne generelt bliver yngre mod sydøst, er der på Big Island den samme aldersprogression, således at de ældste vulkaner og udbrudsprodukter findes mod nord og de yngste mod sydøst. Der er i øjeblikket vulkansk aktivitet fra Kilauea på den sydøstlige del af øen. Den har været i gang kontinuerligt siden januar 1983.

\section{Mauna Kea}

Ekskursionen på den store Hawaiiø begyndte med et besøg på den 4.205 meter høje Mauna Kea. Det er den højeste vulkan både

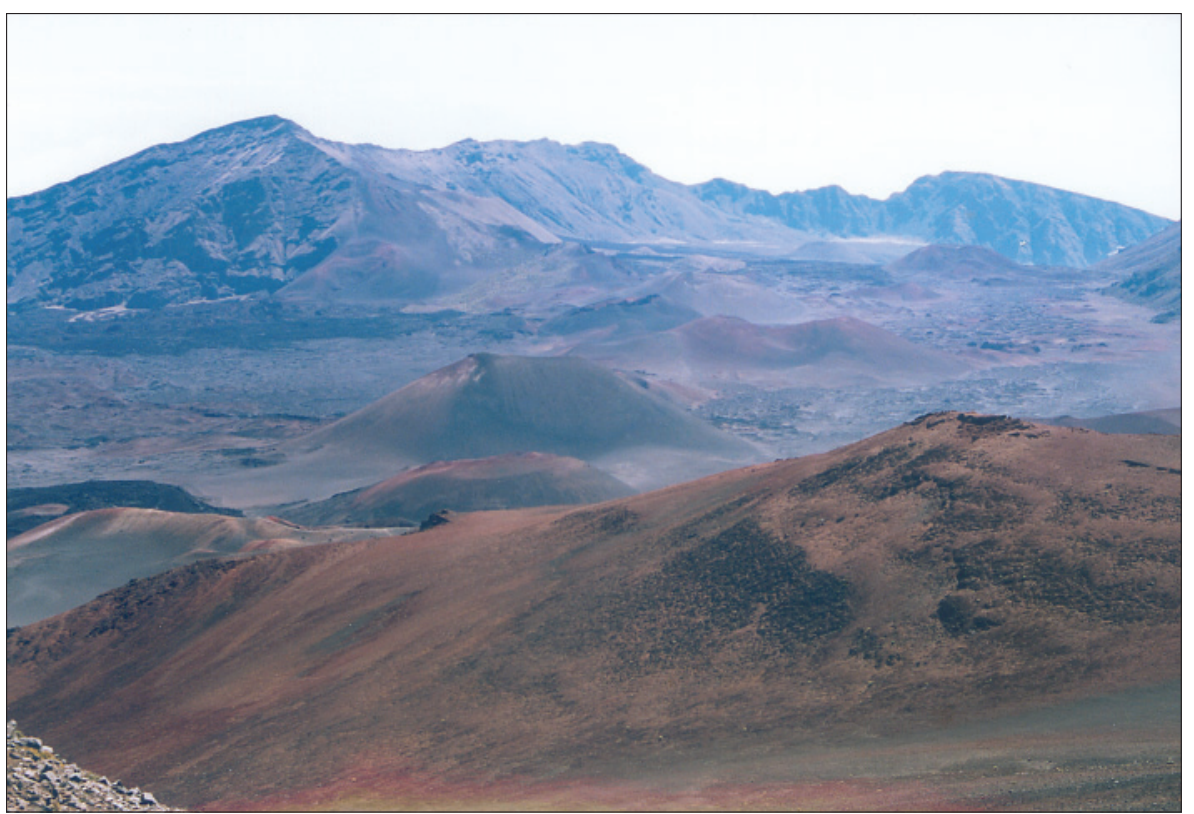

Cinderkeglerne i Haleakala ligger på det ncermeste på en lige linje og indikerer, hvor den senest aktive riftzone er lokaliseret. (Foto: Forfatteren) 
på Big Island og $\mathrm{i}$ øgruppen som helhed. De ældste bjergarter estimeres til at være omkring en million år gamle. Vulkanen befinder sig i "efter-skjoldbygningsfasen" og har været "sovende" siden de seneste udbrud for 6.000 til 4.000 år siden, men er sandsynligvis ikke udslukt. På toppen af Mauna Kea findes verdens største koncentration af forskellige stjernekikkerter og andet rumobservationsudstyr, der er bemandet året rundt.

Der ligger ikke sjældent sne på toppen af Mauna Kea i kortere perioder om vinteren, på trods af at foden af vulkanen ligger i tropisk klima. Faktisk passerer man gennem ikke mindre end 13 forskellige sub-klimazoner, når man kører fra østkysten af Big Island og op på toppen af Mauna Kea.

\section{Hawaii Volcanoes National Park}

På den sydlige del af Big Island er Hawaii Volcanoes National Park etableret og dækker områder med udbrudsprodukter fra vulkanerne Mauna Loa og Kilauea. De første udbrud fra Mauna Loa menes at have fundet sted for omkring en million år siden. Vulkanen er i dag i "skoldbygningsfasen" og 33 historiske udbrud siden 1843 , det seneste i 1984, bringer den op mellem de mest aktive vulkaner på Jorden. Den er samtidig den største vulkan på kloden med sine $17 \mathrm{~km}$ fra basen af vulkanen på havbunden og til toppen i $4.170 \mathrm{moh}$.

Størsteparten af Hawaii Volcanoes Na-

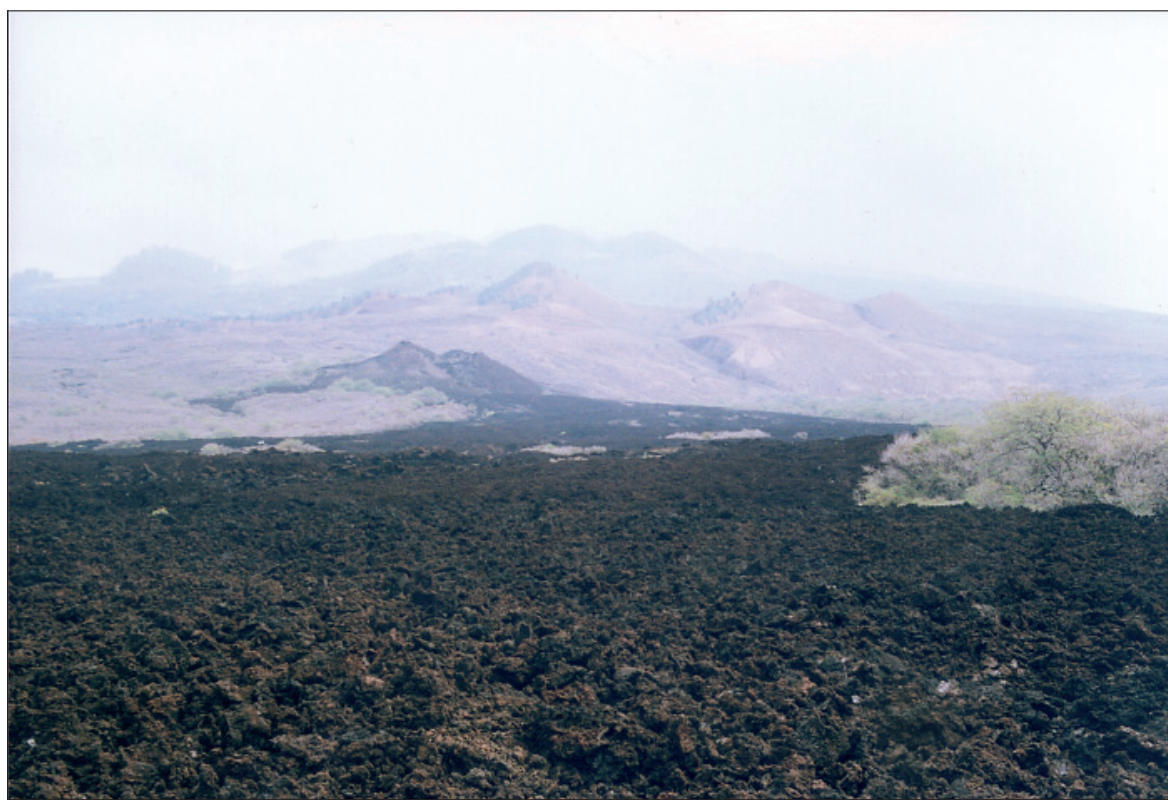

Højden og stejlheden af Østmaui-vulkanen betyder, at den fugtige nordenvind "tørrer ud", så det kun er denne tørre føhnvind, der når over bjerget. Klimaet på sydkysten er derfor tørt, og den sparsomme vegetation består af hårdføre planter. Cinderkeglerne her på sydsiden af Østmaui er lige som cinderkeglerne inde i Haleakala-krateret en overjordisk manifestation af reaktiveringen af tidligere riftzoner. (Foto: Forfatteren)

tional Park ligger på Kilauea-udbrudsprodukter. Kilauea er den mest aktive vulkan på Jorden og befinder sig i den skjoldbyggende fase. Aktiviteten, fra det, vi i dag kender som Kilauea, menes at være startet for mellem 300.000 og 600.000 år siden. Den har sandsynligvis været mere eller mindre kontinuerligt i udbrud i hele sin levetid uden længere perioder med inaktivitet. Den har haft 34 udbrud siden 1952, og det nuvæ-

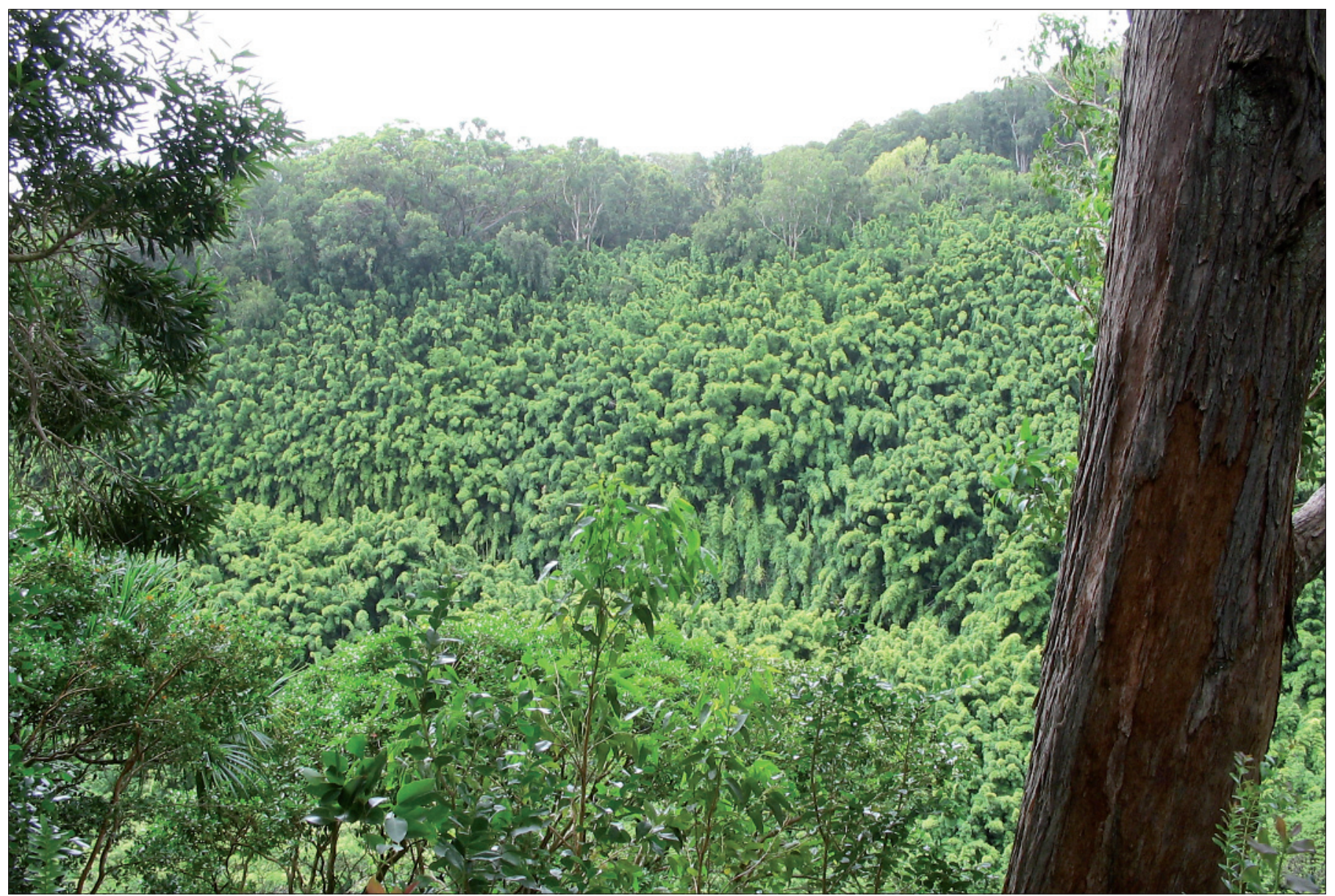

Den fugtige havluft giver gode betingelser for en regnskovsagtig flora på nordkysten af Østmaui-vulkanen. På den modstående skråning her ses blandt andet kampebambus, hvor stammen er optil $10 \mathrm{~cm}$ i diameter. (Foto: Forfatteren) 


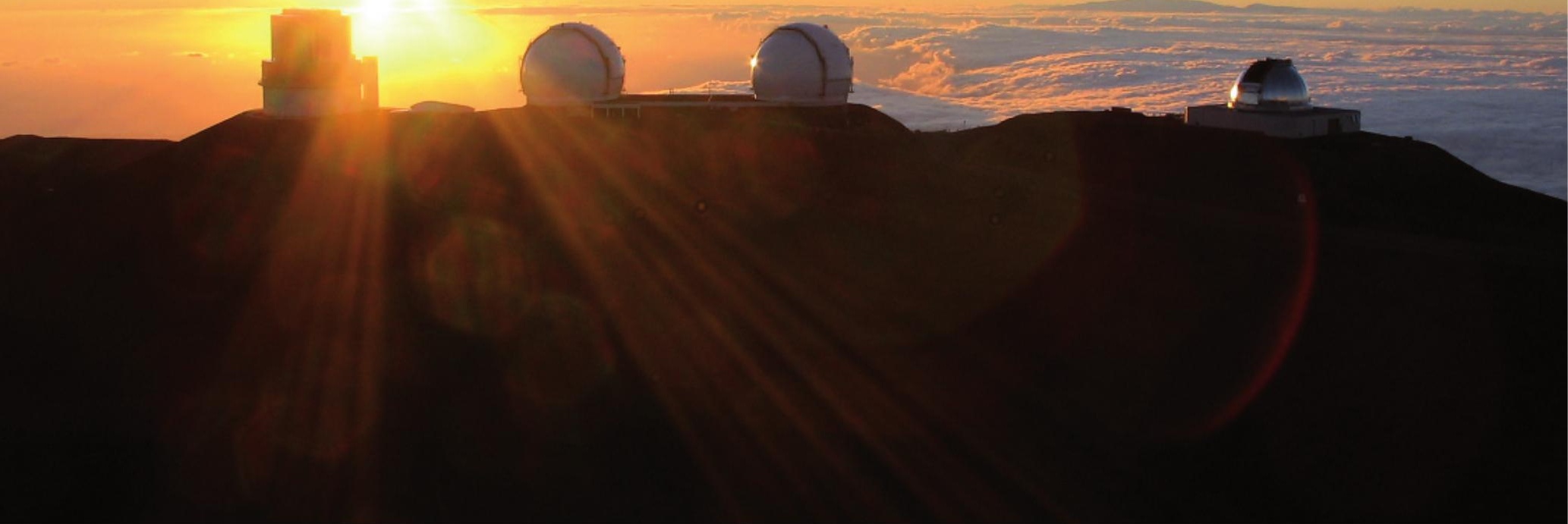

Solnedgang fra Mauna Kea hvor fire af teleskoperne på toppen af vulkanen ses. Teleskopet loengst til højre er allerede åbnet og klar til at arbejde med. Over dette ses Østmaui-vulkanen at stikke op over skyerne. (Foto: Forfatteren)

rende udbrud har været i gang med større eller mindre intensitet siden januar 1983, så den har altså p.t. været kontinuerligt $\mathrm{i}$ udbrud i ca. 23 år. Både dette udbrud og de foregående har skabt mange interessante og særprægede steder.

\section{Lavatræer}

I 1974 var der et lettere eksplosivt udbrud, hvor den flydende lava blev kastet et godt stykke op i luften og landede over et relativt stort område, hvor der blandt andet lå en skov. Træerne brændte selvfølgelig op, men hvor mange af dem stod, står der i dag nogle særprægede lavatræer tilbage. Hvor de er knækket midt over kan man se hul efter stammen og nogle gange også aftryk efter barken.

\section{Størknet lavasø (Kilauea Iki)}

Krateret Kilauea Iki blev dannet ved et udbrud for 350 til 200 år siden. Magmakammeret har på et tidspunkt været næsten tomt, og derfor er der sket et kollaps pga. vægten fra de overliggende bjergarter.

I dag kan man gå på bunden af krateret og går dermed oven på en størknet lavasø. Lavasøer er meget interessante, fordi de

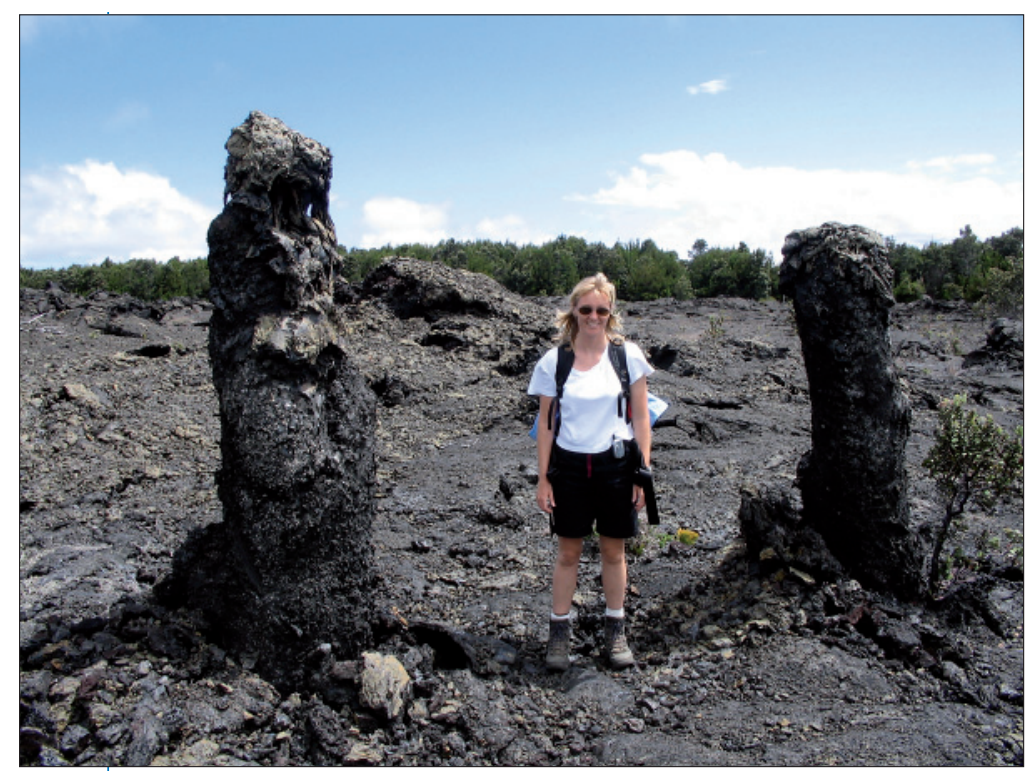

Lavatrceerne ses i mange størrelser og udformninger. Her ses på begge lavatrceer spatter, der har ramt toppen og er løbet lidt ud eller nedad trceet. (Foto: Forfatteren)

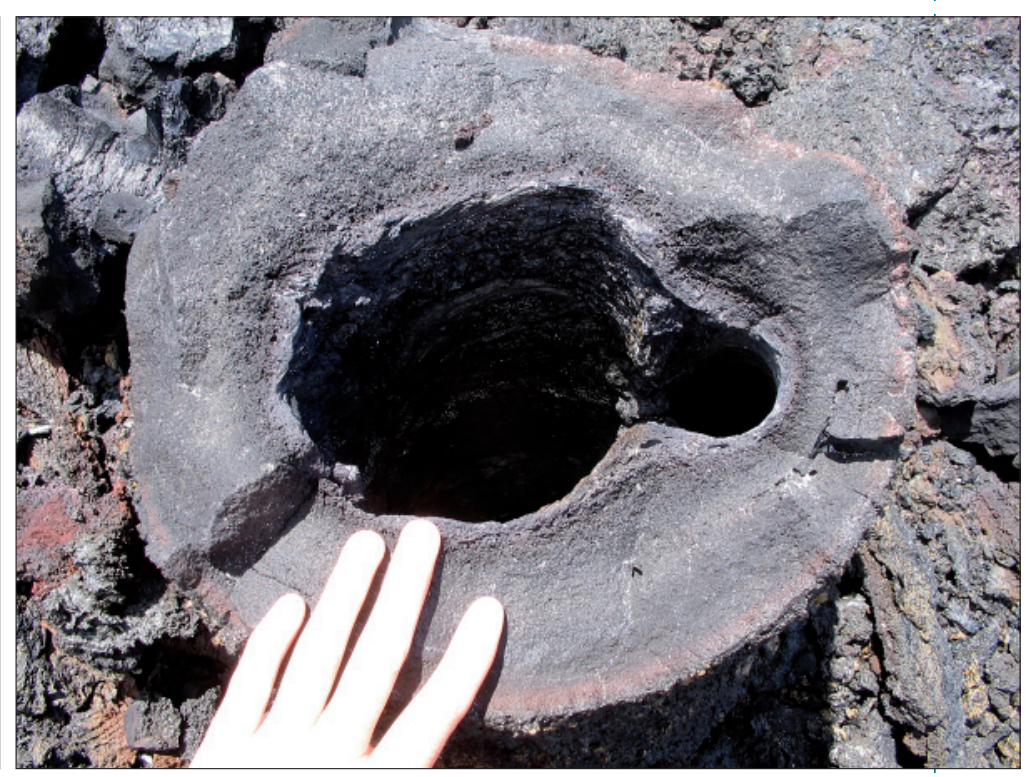

Eksempel på et hul i lavaen efter troestammen. Man kan vore heldig at finde kul nede i sådanne huller. (Foto: Forfatteren) 
kan fortælle noget om processerne, der sker i de ellers utilgængelige magmakamre under jordens overflade.

Der er lavet adskillige boringer her for at studere afkølingsmønstret. Magmaet i Kilauea Iki lavasøen var flydende ved ca. $1.200^{\circ} \mathrm{C}$. Da søen afkøledes, blev der først dannet olivin, dernæst pyroksen og til sidst plagioklas. Da temperaturen var ca. $980^{\circ} \mathrm{C}$, var magmaet fuldstændigt størknet, og ved den seneste boring i 1988 fandtes det eneste tilbageværende flydende materiale langs korngrænserne på mineralerne.

\section{Nuværende aktivitet}

Det nuværende udbrud, der startede i 1983, befinder sig udbrudskaraktermæssigt i en rolig fase. I juli 2005 løb lavaen mest i tunneler under overfladen, og kun enkelte steder kunne man se den rødglødende lava løbe på overfladen. Der var imidlertid flere steder, hvor lavastrømmene nåede havet, og da temperaturforskellen mellem vand og lava er omkring $1.000^{\circ} \mathrm{C}$, er dette møde et flot syn.

Det er dog ikke ufarligt at komme tæt på. Dels udvikles der ubehagelige klordampe ved mødet mellem lava og havvand, og dels er kysten i områderne, hvor lavaen løber ud i vandet, meget ustabil og kan pludselig skride i havet under fødderne på én. Det er somme tider optil flere hektar store områder, der pludselig skrider i havet, og derfor er det heller ikke sikkert at sejle tæt på, da et skred kan skabe en mindre flodbølge.

Lavaen har de senere år mest flydt som rolige pahoehoe-strømme, der udbreder sig i tunger og ofte laver de velkendte rebstrukturer.

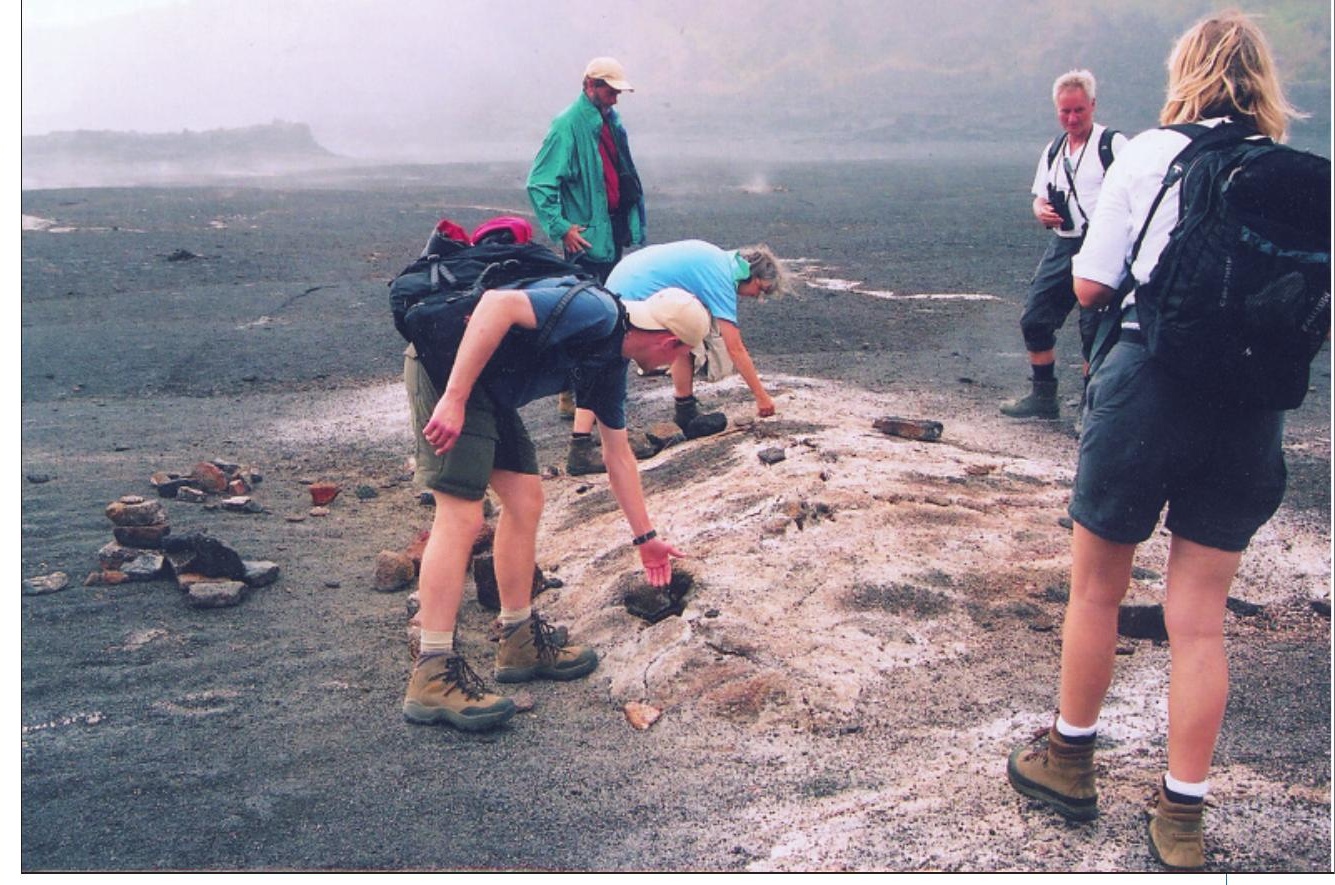

Selvom Kilauea Iki-lavasøen er størknet, kommer der stadig varme op af huller rundt omkring i overfladen, og der aflejres svovl, hvor dampen nedefra kommer i kontakt med luften. Der er ligeledes en tydelig lugt af svovl ved sådanne huller. (Foto: Forfatteren)

\section{Overblik}

Vi har nu meget overfladisk berørt geologien fra den ældste til den yngste af Hawaii-øerne. Man formoder, at den pacifiske lithosfæreplade har bevæget sig så meget $\mathrm{i}$ forhold til hotspottet, at der ikke længere er sandsynlighed for vulkansk aktivitet på Niihau og Kauai. Det er også tvivlsomt, om der vil ske mere på Oahu.

Der er i øjeblikket diskussioner om, hvorvidt den seneste aktivitet på Østmaui overhovedet kan tilhøre den sidste af de fire dannelsesfaser, og om vulkanen ikke

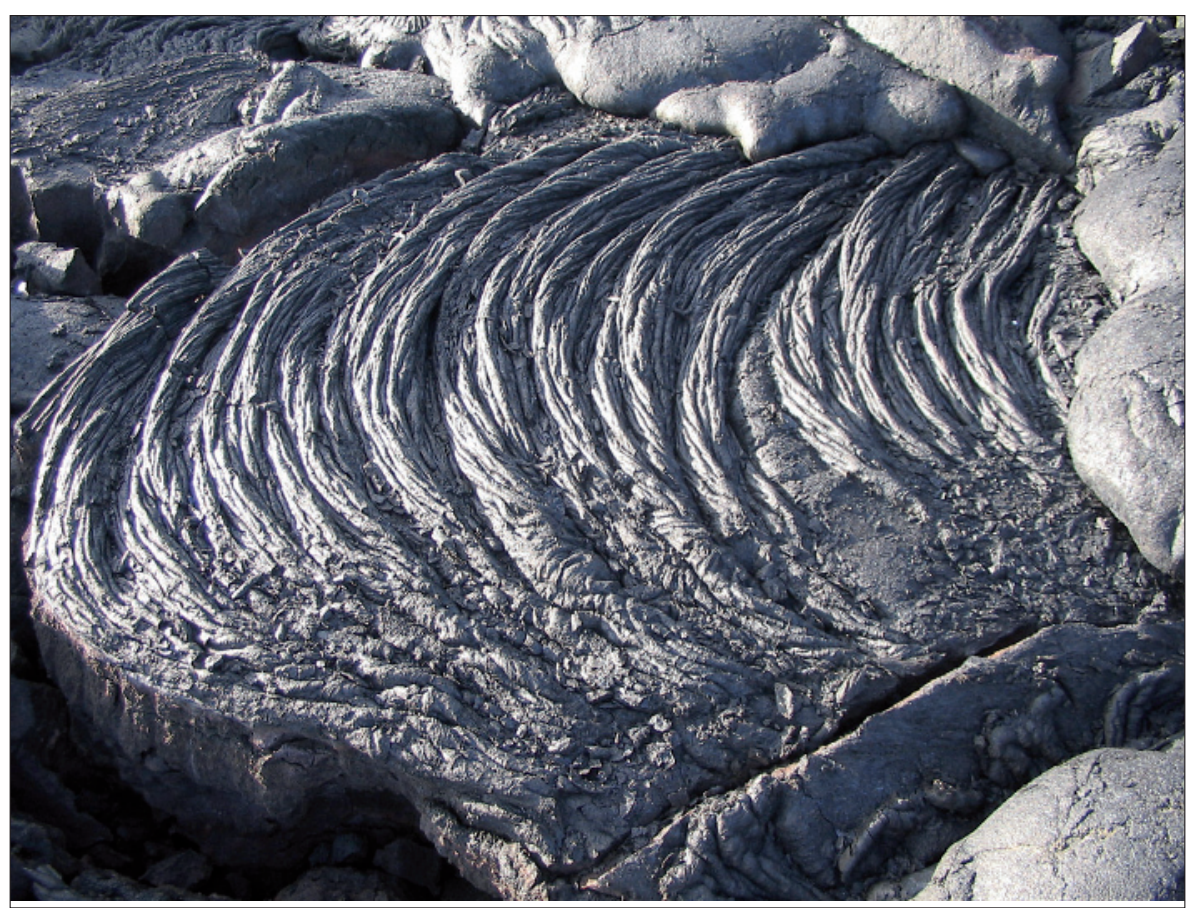

Pahoehoe-lavastrømme fra Kilauea danner meget ofte rebsrukturer, hvor de enkelte reb typisk er 2 - $4 \mathrm{~cm}$ i diameter. Rebene dannes på tvcers af flyderetningen. Rebene på billedet er ca. 3 $\mathrm{cm}$ i diameter. Til højre samt øverst i billedet ses tydelige lavatunger. Lavastrømmen her er fra 2004. (Foto: Forfatteren)

er trådt ind i denne fase endnu.

Under alle omstændigheder er der stor sandsynlighed for, at Maui igen kommer til at opleve vulkansk aktivitet.

På Big Island findes der flere vulkaner, som er i den mest aktive periode af deres "liv", nemlig i skjoldbygningsfasen. Det betyder dog ikke, at de vil være i udbrud hele tiden, som vi ser det fra Kilauea i øjeblikket. Der er dog ikke noget der tyder på, at aktiviteten herfra vil forsvinde lige i nærmeste fremtid, men man ved aldrig. Så se at komme af sted! Ud over Stromboli nord for Sicilien er Hawaii det sted i verden, hvor der er størst sandsynlighed for at få flydende lava at se. 